\title{
EFFECT OF DIFFERENT HARVEST TIMES ON SOME YIELD AND ESSENTIAL OIL CHARACTERISTICS IN Origanum onites L.
}

\author{
Cigdem SONMEZ ${ }^{1 *}$ \\ ${ }^{1}$ Ege University, Faculty of Agriculture, Department of Field Crops, Izmir, TURKEY \\ *Corresponding author:cigdemsnmz@gmail.com
}

Received: 17.05.2019

\begin{abstract}
The purpose of this study was to determine the effects of different harvest times on some yield and quality characteristics in origanum cultivar "Ceylan-2002". Field trial was conducted in 2014 and 2015 at Bornova/Izmir. Oregano plants were harvested starting on 15 of May (harvest time:1), 31 of May (harvest time:2), 16 of June (harvest time:3), 2 of July (harvest time:4), 18 of July (harvest time:5), 3 of August (harvest time:6), 19 of August (harvest time:7) and 4 of September (harvest time:8) and fresh herbage yield, drug herbage yield, drug leaf yield, essential oil content and essential oil yield in each of harvest time were determined. The result from the combined variance analysis over two years for each characteristic indicated that variation among means for harvest time was significant $(p \leq 0.01)$ while differences between two years were not significant for all characteristics. The results showed that the highest drug herbage yield, drug leaf yield and essential oil yield were obtained at the $4^{\text {th }}$ (15 of June) harvest time. It was concluded that the most suitable harvest time in coastal zone of Aegean region is $4^{\text {th }}$ ( 2 of July) harvest time.
\end{abstract}

Keywords: drug herbage yield, drug leaf yield, essential oil content, harvest time, Origanum onites L.

\section{INTRODUCTION}

Several species of genus Origanum are native to the Mediterranean and Turkey is the biggest oregano supplier all around the world (Gungor et al., 2005). Origanum onites L., belongs to Lamiaceae family, is one of the most important species and distribute West and South parts of Turkey which is considered the genetic center of the genus Origanum (Ceylan et al., 2003). Although these regions are known as the main supplier of oregano in the world market (Gungor et al., 2005), collection of the plants from natural flora has led to serious problem in the trade of oregano. For that reason several agronomic studies have been performed in order to establish better cultivation techniques of oregano in field conditions (Ceylan et al., 1999; Sancaktaroglu and Bayram, 2011).

In some previous studies on oregano, plants have been mostly harvested at the beginning of flowering or during the flowering periods. (Otan and Sari, 1994; Ceylan et al., 1994; Arabaci, 1995; Ceylan et al., 1999; Putievsky et al., 1996; Gora et al., 2002; Baydar, 2002; Kirici and Inan, 2001; Bagdat, 2006; Karik et al., 2007 and Kizil et al., 2008). However, in some medicinal plant species, the plant was harvested at different stages of growth and development to determine the optimum harvest time in terms of yield and quality characteristics (Ozguven and
Tanisi, 1998; Gora et al., 2002; Badi et al., 2004; Toncer and Kizil, 2005; Kizil and Toncer, 2006; Telci and Hisil, 2008; Kizil et al., 2008; Kizil et al., 2009; Ramamneh, 2009; Toncer et al., 2010; Kizil et al., 2013; Zawislak and Wierdak, 2014). On the other hand, Otan and Sari (1994), pointed out that the harvesting at beginning of the flowering only in all samples of Origanum onites L. removed the ontogenetic variability. In addition, there has been the lack of knowledge about the effects of harvestings at budding period and beginning of seed setting on yield and quality characteristics in oregano. Therefore, at present study, it was aimed at estimation effects on some yield and quality characteristics of different harvest times and determination the most suitable harvest time in Origanum onites L. in Mediterranean region.

\section{MATERIALS AND METHODS}

Field study was carried out at the experimental area of Field Crops Department, Faculty of Agriculture, Ege University in Bornova/Izmir during 2014 and 2015 growing seasons in semiarid region. Izmir has a typical Mediterranean climatical conditions in the western Turkey. The highest temperature in the area was recorded as $28.3 \mathrm{C}^{\circ}$ in August in the first year, and $28.0 \mathrm{C}^{\circ}$ in July in the second year (Table 1 ). 
Table 1. Temperature and precipitation data of the experimental area at Bornova in 2014-2015 (Anonymus, 2016)

\begin{tabular}{ccccccc}
\hline & \multicolumn{3}{c}{ Mean Temperature $\left({ }^{\circ} \mathbf{C}\right)$} & \multicolumn{3}{c}{ Total Precipitation (mm) } \\
\cline { 2 - 6 } & $\mathbf{2 0 1 4}$ & $\mathbf{2 0 1 5}$ & LYA & $\mathbf{2 0 1 4}$ & $\mathbf{2 0 1 5}$ & LYA \\
\hline January & 9.9 & 8.9 & 9.0 & 113.8 & 125.1 & 112.2 \\
February & 9.7 & 9.5 & 9.2 & 45.6 & 101.9 & 99.7 \\
March & 11.5 & 11.7 & 11.18 & 108.4 & 75.6 & 82.9 \\
April & 15.0 & 15.9 & 16.1 & 76.8 & 46.4 & 46.4 \\
May & 19.3 & 20.8 & 21.0 & 2.2 & 30.9 & 25.4 \\
June & 23.8 & 25.6 & 26.0 & 75.2 & 9.8 & 7.5 \\
July & 26.8 & 28.0 & 28.3 & 16.0 & 1.8 & 2.1 \\
August & 28.3 & 27.7 & 27.9 & 6.0 & 2.6 & 1.7 \\
September & 23 & 23.7 & 23.9 & 18.6 & 15.0 & 19.9 \\
October & 18.8 & 18.8 & 19.1 & 49.0 & 45.3 & 43.2 \\
November & 13.2 & 14.0 & 13.8 & 15.2 & 94.8 & 109.7 \\
December & 11.1 & 10.6 & 10.5 & 206.8 & 141.1 & 137.9 \\
\hline Mean-Total & 17.5 & 17.9 & 18.1 & 753.6 & 690.3 & 688.6 \\
\hline
\end{tabular}

LYA: Long year average

The total annual precipitation was 753.6 and 690.3 $\mathrm{mm}$ in 2014 and 2015, respectively. Experimental area is $31 \mathrm{~m}$ above sea level with mild Mediterranean climate condition. Average temperature and total precipitation are presented in Table 1. Soil texture of the experimental area was generally composed of clay (Table 2). The first $30 \mathrm{~cm}$ soil was clayey loam with $\mathrm{pH}$ of 7.61 and soil of $30-60 \mathrm{~cm}$ deep was clayey loam with $\mathrm{pH}$ of 7.64 in the experimental field (Ekren and Ilker, 2017).

Origanum onites L. cv. "Ceylan-2002" was used as plant material. The seedlings of Origanum onites L. cv. "Ceylan-2002" sown into a mixture of sand, manure and mulch $(1: 1: 1)$ on November 15, 2011. The oregano seedlings were transferred to the experimental plots on
April 10, 2012. Each plot was arranged as three rows at a $0.2 \times 0.4 \mathrm{~m}$ spacing. The field trial was conducted according to Randomized Complete Block Design (RCBD) with three replications. During the vegetation period the plots were uniformly irrigated and weeded when required. Although the first year was not harvested, it was harvested in the second year for stimulated to growing. Oregano plants were harvested done on 15 of May (harvest time:1), 31 of May (harvest time:2), 16 of June (harvest time:3), 2 of July (harvest time:4), 18 of July (harvest time:5), 3 of August (harvest time:6), 19 of August (harvest time:7) and 4 of September (harvest time:8) years in 2014 and 2015. Plants, after removing border effects were cut at a height of $10 \mathrm{~cm}$ above the soil surface and the following characteristics were measured:

Table 2. Some soil physical and chemical characteristics at the experimental field (Ekren and Ilker, 2017).

\begin{tabular}{cccccccccc}
\hline Depth (cm) & Texture & $\begin{array}{c}\text { Total } \\
\text { Soluble } \\
\text { Salt }(\boldsymbol{\%})\end{array}$ & $\begin{array}{c}\text { Organic } \\
\text { matter } \\
(\boldsymbol{\%})\end{array}$ & $\mathbf{p H}$ & $\mathbf{C a C O}(\boldsymbol{\%})$ & Total N & Sand (\%) & Silt (\%) & Clay (\%) \\
\hline $0-30$ & Clayey loam & 0.074 & 2.82 & 7.61 & 23.98 & 0.129 & 28.6 & 39.40 & 32.00 \\
$30-60$ & Clayey loam & 0.080 & 2.72 & 7.64 & 24.65 & 0.101 & 31.00 & 38.60 & 30.40 \\
\hline
\end{tabular}

Fresh herbage yields $\left(t h a^{-1}\right)$ : The plants were harvested by hand with a saw knife, $10 \mathrm{~cm}$ above the surface, and immediately weighed for the obtained plot yields. Then the plot yield was converted to a yield for a hectare.

Drug herbage yields $\left(t h a^{-1}\right)$ : A sample of $500 \mathrm{~g}$ of green herb was taken from each plot. The samples were dried at $35{ }^{\circ} \mathrm{C}$ for $72 \mathrm{~h}$ to determine its dry weight.

Drug leaf yields $\left(t h a^{-1}\right)$ : A sample of $500 \mathrm{~g}$ green herbs was taken from each plot. The leaves and stems of the samples were separated by hand and weighed. The leaves were dried in an oven at $35{ }^{\circ} \mathrm{C}$ for $72 \mathrm{~h}$ to determine the dry weight.

Essential oil content (\%): Dry leaf materials of $10 \mathrm{~g}$ were subjected to a $3 \mathrm{~h}$ water-distillation using a NeoClevenger apparatus, and the extracted essential oils were stored at $4{ }^{\circ} \mathrm{C}$ until the gas chromatography (GC) analysis.
The essential oil ratios of the plants were determined by a volumetric method (ml/100 g) (Wichtl, 1971).

Essential oil yields $\left(I h^{-1}\right)$ : The essential oil yield of each plot was multiplied by drug leaf yield to determine essential oil yield.

The combined variance analysis was performed over two years for the values of all characteristics. All data were statistically analyzed using the TOTEMSTAT statistical program (Acikgoz et al., 2004). The treatment means were compared by using the LSD test as described by Steel and Torrie (1980). Mean over two years in characteristics where interaction of year $\mathrm{x}$ harvest time was non-significant were discussed.

\section{RESULTS AND DISCUSSION}

The result from the combined variance analysis over two years for each characteristic studied was presented in Table 3. The differences among means of harvest time 
were significant $(\mathrm{p} \leq 0.01)$ while differences between two years were not significant for all characteristics. It was observed that the interaction of harvest time $\mathrm{x}$ year was significant for only essential oil content. Therefore, it can be said that the means of harvest time do not vary much according to years in terms of properties except essential oil content. In other words, a consistent effect of harvest time occurred on these characteristics.

Table 3. Mean squares obtained from variance analyses combined over two years for all characteristics

\begin{tabular}{ccccccc}
\hline Source & $\begin{array}{c}\text { Degrees of } \\
\text { fredom }\end{array}$ & $\begin{array}{c}\text { Fresh Herbage } \\
\text { Yield }\end{array}$ & $\begin{array}{c}\text { Drug Herbage } \\
\text { Yield }\end{array}$ & $\begin{array}{c}\text { Drug Leaf } \\
\text { Yield }\end{array}$ & $\begin{array}{c}\text { Essential Oil } \\
\text { Content }\end{array}$ & $\begin{array}{c}\text { Essential Oil } \\
\text { Yield }\end{array}$ \\
\hline Block/Year & 4 & 1.62 & 0.33 & 0.14 & 0.19 & 1575.59 \\
Year & 1 & $3.52^{\mathrm{ns}}$ & $0.32^{\mathrm{ns}}$ & $0.05^{\mathrm{ns}}$ & $0.21^{\mathrm{ns}}$ & $4070.45^{\mathrm{ns}}$ \\
Harvest time & 7 & $156.25^{* *}$ & $33.63^{* *}$ & $10.17^{* *}$ & $0.71^{* *}$ & $23175.54^{* *}$ \\
Year X Harvest & 7 & $6.79^{\mathrm{ns}}$ & $1.43^{\mathrm{ns}}$ & $0.40^{\mathrm{ns}}$ & $0.14^{* *}$ & $806.74^{\mathrm{ns}}$ \\
time & 28 & 13.34 & 2.79 & 0.91 & 0.04 & 1722.96 \\
Error & 28 : significant at the $\mathrm{p} \leq 0.05$ probability level, **: significant at the $\mathrm{p} \leq 0.01$ probability level, ns: not significant & &
\end{tabular}

The means of the years of 2014 and 2015 and also obtained over two years for fresh herbage yield in different harvest times were shown in Table 4. It was found that the year $\mathrm{x}$ harvest time interaction was not significant for fresh herbage yield. The mean of the highest fresh herbage yield was obtained from $4^{\text {th }}$ harvest as $27.36 \mathrm{tha}^{-1}$ while the mean of the lowest one value was found in the first harvest as $10.67 \mathrm{tha}^{-1}$. The fresh herbage yield values for oregano had variations in several studies. The mean values of fresh herbage yields were reported as $10.45 \mathrm{t} \mathrm{ha}^{-1}$ by Kirman (1993), $25.12 \mathrm{t} \mathrm{ha}^{-1}$ by Ceylan et al. (1994) and $12.76 \mathrm{t} \mathrm{ha}^{-1}$ by Ozsoy (1995). Ceylan et al. (1998) who studied on Origanum onites L. was recorded mean of fresh herbage yield as $40.99 \mathrm{t} \mathrm{ha}^{-1}$. Bayram et al. (1999) determined that fresh herbage yield of Origanum onites L. varied between $26.21 \mathrm{t} \mathrm{ha}^{-1}$ and $45.34 \mathrm{t} \mathrm{ha}^{-1}$. However, Avci (2006) who investigated yields and some quality characteristic of different 14 oregano clones found that the fresh herbage yields varied from $13.37 \mathrm{t} \mathrm{ha}^{-1}$ to $37.33 \mathrm{t} \mathrm{ha}^{-1}$ under Aegean ecological conditions. Our result for fresh herbage yield was higher than those obtained by Kirman (1993) and Ozsoy (1995) while being less than those Ceylan et al. (1998) and Bayram et al. (1999). On the other hand, these findings are in agreement with the results of Ceylan et al. (1994) and Avci (2006).

Table 4. Means of studied characters of cultivar Ceylan-2002 at harvest times.

\begin{tabular}{|c|c|c|c|c|c|c|c|c|c|c|c|c|c|c|c|}
\hline \multirow{2}{*}{ 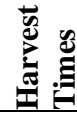 } & 2014 & 2015 & Mean & 2014 & 2015 & Mean & 2014 & 2015 & Mean & 2014 & 2015 & Mean & 2014 & 2015 & Mean \\
\hline & \multicolumn{3}{|c|}{$\begin{array}{c}\text { Fresh Herbage } \\
\text { Yield }\left(\mathrm{t} \mathrm{ha}^{-1}\right)\end{array}$} & \multicolumn{3}{|c|}{$\begin{array}{c}\text { Drug Herbage } \\
\text { Yield }\left(\mathrm{t} \mathrm{ha}^{-1}\right)\end{array}$} & \multicolumn{3}{|c|}{$\begin{array}{c}\text { Drug Leaf } \\
\text { Yield }\left(\mathrm{t} \mathrm{ha}^{-1}\right)\end{array}$} & \multicolumn{3}{|c|}{$\begin{array}{l}\text { Essential Oil } \\
\text { Content }(\%)\end{array}$} & \multicolumn{3}{|c|}{$\begin{array}{l}\text { Essential Oil } \\
\text { Yield }\left(\mathbf{l ~ h a}^{-1}\right)\end{array}$} \\
\hline 1 & 10.79 & 10.54 & $10.67^{\mathrm{d}}$ & 4.33 & 4.47 & $4.40^{\mathrm{d}}$ & 2.63 & 2.71 & $2.67^{\mathrm{cd}}$ & $3.42^{\mathrm{d}}$ & $3.52^{\mathrm{cd}}$ & $3.47^{\mathrm{d}}$ & 68.64 & 95.39 & $82.01^{\mathrm{d}}$ \\
\hline 2 & 14.67 & 13.24 & $13.96^{\mathrm{cd}}$ & 6.52 & 5.75 & $6.14^{\mathrm{cd}}$ & 3.84 & 3.39 & $3.61^{\mathrm{cd}}$ & $4.47^{\mathrm{a}}$ & $4.52^{\mathrm{a}}$ & $4.49^{\mathrm{a}}$ & 155.51 & 152.90 & $154.20^{\mathrm{c}}$ \\
\hline 3 & 21.83 & 19.55 & $20.69^{b}$ & 9.98 & 8.56 & $9.27^{b}$ & 5.72 & 4.91 & $5.31^{\mathrm{b}}$ & $4.38^{\mathrm{a}}$ & $4.52^{\mathrm{a}}$ & $4.45^{\mathrm{ab}}$ & 228.94 & 221.57 & $225.25^{\mathrm{ab}}$ \\
\hline 4 & 27.15 & 27.56 & $27.36^{\mathrm{a}}$ & 12.34 & 12.22 & $12.28^{\mathrm{a}}$ & 7.05 & 6.98 & $7.02^{\mathrm{a}}$ & $3.75^{\mathrm{bcd}}$ & $4.58^{\mathrm{a}}$ & $4.17^{\mathrm{bc}}$ & 259.17 & 320.38 & $289.77^{\mathrm{a}}$ \\
\hline 5 & 21.91 & 22.66 & $22.28^{\mathrm{ab}}$ & 9.46 & 9.89 & $9.67^{\mathrm{ab}}$ & 5.21 & 5.44 & $5.32^{b}$ & $4.52^{\mathrm{a}}$ & $4.42^{\mathrm{a}}$ & $4.47^{\mathrm{ab}}$ & 237.80 & 240.05 & $238.93^{\mathrm{ab}}$ \\
\hline 6 & 21.13 & 21.06 & $21.09^{b}$ & 9.09 & 9.37 & $9.23^{b}$ & 4.87 & 5.03 & $4.95^{b c}$ & $4.28^{\mathrm{ab}}$ & $4.35^{\mathrm{a}}$ & $4.32^{\mathrm{abc}}$ & 208.51 & 219.12 & $213.81^{\mathrm{bc}}$ \\
\hline 7 & 17.08 & 20.87 & $18.97^{\mathrm{bc}}$ & 7.81 & 9.46 & $8.64^{b c}$ & 3.82 & 4.63 & $4.23^{b c}$ & $4.03^{\mathrm{abc}}$ & $4.18^{\mathrm{ab}}$ & $4.11^{\mathrm{c}}$ & 154.81 & 194.04 & $174.43^{\mathrm{bc}}$ \\
\hline 8 & 17.93 & 21.34 & $19.63^{\mathrm{bc}}$ & 8.19 & 9.29 & $8.74^{\mathrm{bc}}$ & 4.02 & 4.57 & $4.30^{\mathrm{bc}}$ & $4.53^{\mathrm{a}}$ & $4.37^{\mathrm{a}}$ & $4.45^{\mathrm{ab}}$ & 182.40 & 199.69 & $191.05^{\mathrm{bc}}$ \\
\hline Mean & 19.06 & 19.60 & 19.33 & 8.46 & 8.63 & 8.55 & 4.65 & 4.71 & 4.68 & 4.17 & 4.31 & 4.24 & 186.97 & 205.39 & 196.18 \\
\hline LDS & $\begin{array}{l}\text { Y:ns } \\
\text { HI: } 5 . \\
\text { YxHI: }\end{array}$ & $\begin{array}{l}4 * * \\
\text { as }\end{array}$ & & $\begin{array}{l}\text { Y:ns } \\
\text { HI:2.6 } \\
\text { YxHI }\end{array}$ & & & $\begin{array}{l}\text { Y:ns } \\
\text { HI: } 1 . \\
\text { YxHI }\end{array}$ & & & $\begin{array}{l}\text { Y: ns } \\
\text { HI: } 0.3 \\
\text { YxHI: }\end{array}$ & $\begin{array}{l}* * \\
43 * *\end{array}$ & & $\begin{array}{l}\text { Y:ns } \\
\text { HI:66.4 } \\
\text { YxHI:n }\end{array}$ & & \\
\hline
\end{tabular}

*: significant at the $\mathrm{p} \leq 0.05$ probability level, **: significant at the $\mathrm{p} \leq 0.01$ probability level, ns: not significant

The means of the years of 2014 and 2015 and also obtained over two years for drug herbage yield in different harvest times were shown in Table 4. It was found that the year $\mathrm{x}$ harvest time interaction was not significant for drug herbage yield. The highest drug herbage yield was recored as $12.28 \mathrm{t} \mathrm{ha}^{-1}$ at $4^{\text {th }}$ harvest and also the smallest values was observed as $4.40 \mathrm{t} \mathrm{ha}^{-1}$ at the $1^{\text {st }}$ harvest. A wide variation appeared in results of various researchers about drug herbage yields. The mean of drug herbage yield was reported as $3.57 \mathrm{t} \mathrm{ha}^{-1}$ by Kirman (1993). Ceylan et al. (1994) studied on Origanum onites L. and determined a mean value of $8.20 \mathrm{t} \mathrm{ha}^{-1}$. In a study counducted under in Izmir ecological conditions, the mean of drug herbage yield was found to be 12.76 tons per hectare (Ceylan et al. 1999). Kirici and Inan (2001) reported that the highest drug herbage yield was $5.36 \mathrm{t} \mathrm{ha}^{-1}$ in a Mediterranean environment. However, Baydar (2002), recorded that the mean drug herbage yield of oregano was $2.30 \mathrm{t} \mathrm{ha}^{-1}$ in Isparta location. Gungor (2002) reported that the drug herbage yield of oregano altered between 1.58 tons and 8.03 tons per hectare whereas Avci (2006) obtained that the drug herbage yields varied from $5.13 \mathrm{t} \mathrm{ha}^{-1}$ to $11.29 \mathrm{t}$ $\mathrm{ha}^{-1}$. When the our result for drug herbage yields were compared with previous studies, the mean value in this study was higher than Kirman (1993); Ceylan et al. (1994); Kirici and Inan (2001); Baydar (2002) and Gungor (2002). Also, it is agreement with the findings of Ceylan et al. (1999) and Avci (2006).

The means of the years of 2014 and 2015 and also obtained over two years for drug leaf yield in different harvest times were shown in Table 4 . The effect of year $x$ 
harvest time interaction on the drug leaf yield was not significant. The highest value was still obtained as 7.02 tons per hectare at $4^{\text {th }}$ harvest and the lowest values were realized in first and second harvest times under Bornova ecological conditions as 2.67 and 3.61 tons per hectare, respectively. Origanum onites L.. In the various studies on Origanum onites L., different results varied from 2.57 to 8.65 tons per hectare were obtained (Kirman, 1993; Ceylan et al.,1994; Bayram et al., 1999; Ceylan et al., 1999 and Avci, 2006 ). But Gungor (2002) stated that these values ranged from $1.58 \mathrm{t} \mathrm{ha}^{-1}$ to $8.03 \mathrm{t} \mathrm{ha}^{-1}$. The mean values from our study were found to be higher than those of Kirman (1993) and Ceylan et al. (1994) while being compatible with Bayram et al. (1999); Ceylan et al. (1999); Gungor (2002) and Avci (2006).

The means of the years of 2014 and 2015 and also obtained over two years for essential oil content was presented in Table 4. This research showed that year $\mathrm{x}$ harvest time interaction was significant for essential oil content. This case pointed out that the mean values obtained from some harvest times had varied according to years. It was observed that the differences among means of $2^{\text {nd }}, 3^{\text {th }}, 5^{\text {th }}$ and $8^{\text {th }}$ harvest times were not significant and also they had the highest means of essential oil content over two years. Essential oil content (EO) of Origanum onites L. has been studied in many researches. This character could be affected by treatments, environmental condition and genetic factors. In the some previous studies on Origanum onites L., mean values varied from $2 \%$ to $6.12 \%$ were obtained (Kirman, 1993; Arabaci, 1995; Kirici and Inan, 2001; Ozel and Kaymaz, 2004 and Avci, 2006). The means in this study were higher than those of Kirman (1993); Ceylan et al. (1994); Arabaci (1995); Kirici and Inan (2001) while being in agrement with results of Ozel and Kaymaz (2004) and Avci (2006).

The means of the years of 2014 and 2015 and also obtained over two years for essential oil yields (EOY) in different harvest times were shown in Table 4 . The year $\mathrm{x}$ harvest interaction was not significant for essential oil yield. The mean of highest essential oil yield was recorded as $289.771 \mathrm{ha}^{-1}$ in full flowering period ( $4^{\text {th }}$ harvest). However, the mean essential oil yield was lowest $1^{\text {st }}$ harvest time. Although less essential oil content mean in $4^{\text {th }}$ harvest time was realized than means of $2,3,5,6$ and $8^{\text {th }}$ harvest times over two years, the highest essential oil yield was obtained in harvest time mentioned $\left(4^{\text {th }}\right)$ because its drug leaf yield was higher than those of others. Avci (2006), reported that EOY of Origanum onites L. was varied between 122.3 and 249.01 ha-1 in different Origanum onites L. clones collected from western Anatolia flora while Kizil et al. (2008), stated that EOY of oregano (Origanum onites L.) was varied between 119.31 and 190.11 per hectare in different development stages. The EOY mean in present study was higher than those of Baydar (2002); Kan et al. (2005) and Kizil et al. (2008) but it's in agreement with result of Avci (2006), when compared.

\section{CONCLUSION}

Based on the discussion of the results of this study the following conclusions could be drawn. It was found that the highest mean values were obtained at the time of $4^{\text {th }}$ harvest (full flowering), and also the lowest mean values were observed at the time of $1^{\text {st }}$ harvest (growth vegetation). The fact that year $\mathrm{x}$ harvest time interactions were not significant in all characteristics except the essential oil content, indicated that the differences among the means of harvest times did not change according to years. The drug leaf yield in oregano is a component of the drug herbage yield. Although in the $3^{\text {rd }}$ and $5^{\text {th }}$ harvest times the drug leaf yield means had significantly lower than that of $4^{\text {th }}$ harvest time, because these two harvest times $\left(3^{\text {rd }}\right.$ and $\left.5^{\text {th }}\right)$ had higher essential oil content, the mean values for essential oil yields were found to be included in the same statistical groups with $4^{\text {th }}$ harvest time (225.25 and 238.931 ha $^{-1}$, respectively).

As a result, it is observed that the most suitable harvest time in coastal zone of Aegean region is $4^{\text {th }}$ ( 2 of July) harvest time. However, in case of possible delays in harvesting, it may be also harvested in $5^{\text {th }}$ (18 of July) harvest time. In order to obtain the highest drug leaf and essential oil yields, the harvest seems possible in a period from the beginning of flowering to the end of flowering in Aegean region.

\section{LITERATURE CITED}

Acikgoz, N., E. Ilker, A. Gokcol. 2004. Evaluation of biological research on the computer. E.U. TOTEM No:2 (in Turkish).

Arabaci, O. 1995. Izmir oregano (Origanum onites L.)'s growing technical and quality specifications. Ph.D. Thesis. Graduate School of Natural and Applied Sciences. Ege University. 125 $\mathrm{p}$ (in Turkish).

Anonymous. 2016. Bornova Meteorological Data of Olive Research Institute, Izmir

Avci, A. B. 2006. Determination of some agronomic and technological properties in different ecological conditions of improved of Izmir oregano (Origanum onites L.) clones. Ph.D. Thesis. Graduate School of Natural and Applied Sciences. Ege University. 153 p (in Turkish).

Badi, H. N., D. Yazdani, S. M. Ali, F. Nazari. 2004 Effects of spacing and harvesting time on herbage yield and quality/quantity of oil in thyme, Thymus vulgaris L. Industrial Crops and Products. 19:231-236.

Bagdat, R. B. 2006. Uses of medicinal plants, sage (Salvia officinalis L.) and the techniques of depositing species known as thyme in our country. Journal of Field Crops Central Research Institute. 15(1-2):19-28. (in Turkish).

Baydar, H. 2002. Investigations on the yield and quality of the essential oil of Izmir oregano (Origanum onites L. ) under Isparta conditions. Suleyman Demirel University Institute of Science Institute. 6(2):17-24. (in Turkish).

Baydar, H. 2005. Effect of different collected times on the volatile oil content and volatile oil components on plateau oregano (Origanum minutiflorum o. schwarz) Suleyman Demirel University Institute of Science Institute. 6(2):17-24. (in Turkish).

Bayram, E., H. Geren. A. Ceylan, N. Ozay. 1999. The effect of different shape heights on the yield and quality of Izmir oregano (Origanum onites L.). Turkish 3. Congress of Field Crops. 15-18 November. Adana. I:222-226. (in Turkish). 
Ceylan, A. A.Vomel, E. Nigdeli. 1998. Investigations on adaptation and breeding of Izmir oregano (Origanum syriacum L.). I. Program for the symposium of forest products. (in Turkish).

Ceylan, A., E. Bayram and H. Geren. 1999. Investigation on agronomic and quality characteristics of improved clones in Origanum (Origanum onites L.) breeding, Turkish Journal of Agriculture and Forestry. 23:1163-1168.

Ceylan, A., E. Bayram, N. Sahbaz, H. Otan and S. Karaman. 2003. Yield performance and essential oil composition of individual plants and improved clones of Origanum onites L. grown in Aegean Region of Turkey. Israel Journal of Plant Sci. 51:285-290.

Ceylan, A., H. Otan, M. Polat, E. Bayram, O. Sari, N. Ozay, S. Kudat, N. Çarkıcı, B. Oguz, A. Kitiki. 1994. Origanum onites $\mathrm{L}$. (Izmir oregano) on agrotechnical investigations. T. C. Ministry of Agriculture and Rural Affairs General Directorate of Agricultural Research. Aegean Agricultural Research Institute Report. (in Turkish).

Ekren, S. and E. Ilker. 2017. The Influence of Clipping Application on Yield and Some yield Parameters of Aegean Types Tobaccos. Turkish Journal of Field Crops 22(2):218226.

Gora, J., A. Lis, J. Kula, M. Staniszewska and A. Woloszyn. 2002. Chemical composition variability of essential oils in the ontogenesis of some plants. Flavour and Fragrance Journal. 17:445-451.

Gungor, F. U. 2002. Comparison of clones developed in Izmir oregano (Origanum onites L.) clones in terms of agronomic and quality. Ph.D. Thesis. Graduate School of Natural and Applied Sciences. Ankara University. 74 p (in Turkish).

Gungor, F.U., N. Bayraktar and M.D. Kaya. 2005. Comparison of improved clones of Izmir oregano (Origanum onites L.) for agronomic and quality characteristics under Kula conditions. Journal of Agricultural Sciences 11(2): 196-200.

Kan, Y., L. Altun, S. Arslan, M. Kartal, Z. Endes. 2005. effect of organic manure applied at different doses on the yield and quality of Izmir oregano (Origanum onites L.). Turkish VI. Congress of Field Crops. 5-9 September. Antalya. I:497-500. (in Turkish).

Karik, U., A.B. Tinmaz, M. Kurkcuoglu, K. H. C. Baser, G. Tumen. 2007. Effects of different harvest times on yield and quality in Istanbul oregano (Origanum vulgare subsp. hirtum) populations. Bahce 36(1-2):37-48. (in Turkish).

Kirici, S. and M. Inan. 2001. The effect of different harvesting times of oregano (Origanum syriacum var. bevanii) on yield and yield components in Cukurova conditions. Turkish 4. Congress of Field Crops. 17-21. September. Tekirdag. II:291-294. (in Turkish).

Kirman, H. 1993. Research on the determination of some agronomic and quality characteristics of improved Izmir oregano (Origanum onites L.) lines. Master Thesis. Graduate School of Natural and Applied Sciences. Ege University. 39 $\mathrm{p}$ (in Turkish).

Kizil , S., A. Ipek , N. Arslan and K. M. Khawar. 2008. Effect of different developing stages on some nagronomical characteristics and essential oil composition of Oregano (Origanum onites). New Zealand Journal of Crop and Horticultural Science 36: 71-76.

Kizil, S. and O. Toncer. 2006. Influence of different harvest times on the yield and oil composition of spearmint (Mentha spicata L. var. spicata). Journal of Food, Agriculture \& Environment. 4 (3\&4): 135-137.
Kizil, S., M. Inan and S. Kirici. 2013. Determination of the Best Herbage Yield and Hypericin Content of St. John's wort (Hypericum perforatum L.) under Semi Arid Climatic Conditions. Turkish Journal of Field Crops 18(1): 95-100.

Kizil, S., M. Turk, M. Ozguven, K. M. Khawar. 2009. Full Blooming Stage is Suitable for Herbage Yield and Essential Oil Content of Summer Savory (Satureja hortensis L.). Journal of Essential Oil Bearing Plants 12 (5): 620-629.

Kizil, S., O. Toncer, A. Ipek, N. Arslan, S. Saglam and K. M. Khawar. 2008. Blooming stages of Turkish hyssop (Hyssopus officinalis L.) affect essential oil composition Acta Agriculturae Scandinavica Section B-Soil and Plant Science. 58: 273-279.

Otan, H. and A. O. Sari. 1994. Some quality characteristics of Origanum onites L. (Izmir oregano) populations in western Anatolian flora. Turkish Congress of Field Crops. Agronomy Reports 1. 25-29 April. Izmir.146-149.

Ozel, M.Z. and H. Kaymaz. 2004. Superheated water extraction, steam distillation and soxhelet extraction of essential oils of Origanum onites. Analytical and Bioanalytical Chemistry 379(7-8): 1127-1133.

Ozguven, M. and S. Tansi. 1998. Drug Yield and Essential Oil of Thymus vulgaris L. as in Influenced by Ecological and Ontogenetical Variation. Turkish Journal of Agriculture and Forestry 22: 537-542.

Ozsoy, U. E. 1995. Investigations on some agronomic and quality characteristics of the Izmir oregano (Origanum onites L.) populations collected from Mugla region. Master Thesis. Graduate School of Natural and Applied Sciences. Ege University. $67 \mathrm{p}$ (in Turkish).

Putievsky, E., U. Ravid, N. Dudai. 1996. Cultivation, selection and conservation of oregano species in Isreal. Promoting the conservation and use of underutilized and neglected crops. 14.Oregano. Proceedings of the IPGRI International Workshop on Oregano. 8-12 May. CIHEAM. Valenzo. Bari Italy.

Ramamneh, E. A. D. M. A. 2009. Plant growth strategies of Thymus vulgaris L. in response to population density. Industrial Crops and Products 30:389-394.

Sancaktaroglu, S. and E. Bayram. 2011. Researches on the determination of the yields and quality characteristics of Istanbul oregano populations (Origanum vulgare subsp. hirtum L.) of the different origin. The Journal of Ege University Faculty of Agriculture. 48: 265-276 (in Turkish).

Steel, R.G.D. and J.H. Torrie. 1980. Principles and procedures of statistics. McGaw-Hill book Company. Inc. N.Y.

Telci, I. and Y. Hisil. 2008. Biomass Yield and Herb Essential Oil Characters at different Harvest Stages of Spring and Autumn Sown Coriandrum sativum. Europian Journal of Hort.Sci. 73 (6): 267-272.

Toncer, O. and S. Kizil. 2005. Determination of yield and yield components in wild thyme (Thymbra spicata L. var. spicata) as influenced by development stages. Horticulture Science (PRAGUE). 32(3): 100-103.

Toncer, O., S. Karaman and E. Diraz. 2010. An annual variation in essential oil composition of Origanum syriacum from Southeast Anatolia of Turkey. Journal of Medicinal Plants Research 4(11): 1059-1064.

Wichtl, M. 1971. Die Pharmakognostichemische Analys, Band 2., Frankfurt/M.

Zawislak, G. and R. N. Wierdak. 2014. Evaluation of the yield and biological value of tarragon (Artemisia dracunculus L.) in the bunch harvest cultivation. Acta Sci. Pol. Hortorum Cultus. 13(4): 185-198. 